\title{
Mapping Oceania past and present: movements, geographies, identities
}

Anne Di Piazza, Wolfgang Kempf and Erik Pearthree

\section{Q OpenEdition}

Electronic version

URL: http://journals.openedition.org/jso/911

DOI: 10.4000/jso.911

ISSN: 1760-7256

\section{Publisher}

Société des océanistes

\section{Printed version}

Date of publication: 1 December 2007

Number of pages: $209-212$

ISBN: 978-2-85430-010-9

ISSN: 0300-953x

\section{Electronic reference}

Anne Di Piazza, Wolfgang Kempf and Erik Pearthree, « Mapping Oceania past and present: movements, geographies, identities », Journal de la Société des Océanistes [Online], 125 | Année 2007-2, Online since 01 December 2010, connection on 01 May 2019. URL : http://journals.openedition.org/ jso/911 ; DOl : 10.4000/jso.911

\section{(c) Tous droits réservés}




\title{
Mapping Oceania past and present: movements, geographies, identities ${ }^{1}$
}

by

\author{
Anne DI PIAZZA*, Wolfgang KEMPF ** and Erik PEARTHREE
}

\begin{abstract}
Oceania has always been a place of exchanges, of contacs and interactions, in brief of movements. In this session, we have investigated the themes of ancient migration routes through computer simulation; of modes of maritime and terrestrial representations of space; and finally of the dialectic between mobility and enrootedness over the long term and in relation to cultural or colonial hegemony. The primary objective being to question ideas of Oceanic unity and identity through the adaptation of an insular perspective.
\end{abstract}

KeYwords: Oceania, migration routes, spatial representations, mobility, enrootedness.

Oceania has always been home to movements and extensions, to contacts and articulations. In this session we explored avenues of exchange between the various disciplines and approaches, injecting into the discussion a broad band of themes and models, times and spaces. The better to structure this targeted terrain, we isolated three dimensions as likely to repay closer attention:

1) Early projects to settle the Pacific, along with recent computer simulations of migratory routes and emergent modes of representing maritime space.

\section{RÉSUMÉ}

L'Océanie a toujours été un lieu d'échanges, de contacts et interactions, en somme de mouvements. Dans cette session, nous avons abordé les thèmes des routes migratoires anciennes à travers les modélisationssimulations informatiques; des modes de représentation de l'espace maritime et terrestre ; enfin de la dialectique mobilité - enracinement sur le long terme en rapport avec les hégémonies culturelles ou coloniales. L'objectif premier étant de questionner l'unité et l'identité océanienne en adoptant une perspective insulaire.

MoTS-CLÉS : Océanie, routes migratoires, représentation de l'espace, mobilité, enracinement.

2) The epoch of cultural upheavals and cleavages, displacements and relocalisations, as wrought by imperial leverage and hegemonic penetration.

3) Contemporary transnational flows of migrants, money, ideas, images and objects, with all that this implies for the agency and identity of Pacific Islanders, both at home and abroad.

Navigating these multivalent time-spaces of Oceanian entwinements and interdependencies,

1. Presentation of the first session ot the $6^{\text {th }}$ Conference of the European Society for Oceanists, at Marseille (July 8-10 2005).

* CNRS-CREDO, Marseille, dipiazza@wanadoo.fr

** University of Göttingen, Germany, wkempf@uni-goettingen.de 
we set out to trace the analytic potential of two different strands:

1) a spatial anthropology seeking to build conceptual, analytical and predictive models;

2 ) the tracking of cultural and historical processes involving indigenous constructions and reconfigurations of social-spatial alignments and attachments.

Our aim was to isolate and identify such relational constitutings and entwinings of place, culture and identity as are poised between mobility and abiding.

\section{Part I: Oceania in Flux - Contemporary Issues (Wolfgang Kempf)}

The theoretical point of departure for our session was a general paradigm switch in the cultural sciences, one that, by picking up on the currents, network effects and transformations in local, regional and transnational spaces, has called into question the earlier paradigm of the unity of place, culture and identity. For Oceania this means there is no way back to an insular perspective of clearly circumscribed, discretely localised cultures, where Samoans, for example, live out their Samoan culture only in Samoa, and where the human-place-culture nexus is postulated as a natural, essential constant. Instead - this very much the result of an abiding interest in such matters as travel, exile, migration, diaspora, trans-nationality and border zones - our theoretical instruments have undergone «remetaphorisation» to the point where they now conceive movement and displacement as forces in the making of place, culture and identity (Clifford, 1992, 1997; Gupta and Ferguson, 1997; Lavie and Swedenburg, 1996; Olwig and Hastrup, 1997; Pile and Thrift, 1995). This dynamic mode of conceptualising how humans identify themselves with specific places and/or territories points the analytic focus to all those contacts and flows, relationships and incorporations that transcend by far the local level.

It goes without saying that earlier studies on Oceania as a region have also, indeed long ago well before the recent gravitation to a globalised terrain of «complex connectivities» (Tomlinson, 1999) - directed attention to diffusion, networks, mobility, voyaging and migration. Yet texts such as Greg Dening's (1980, 1998, 2004) addressing the limen of the beach, Epeli Hau'ofa's seminal «Our sea of islands» (1993) and Karen Nero's conjectured «[The] End of Insularity» (1997) point to a profound change in the analytic focus trained on Oceanian cultures, one pre-figured in such clear-sighted metaphors as «the tree and the canoe» of Joël Bonnemaison (1985). Whether our analyses of Oceanian societies deal with historical or with contemporary themes, the general challenge facing them is to further develop a relational understanding of place, culture and identity in Oceania, one attuned no less to movement and mobility than to staying at home and stability. For all the diversity of ways of conceiving the interdependencies between mobility and abiding, a common theoretical concern might be as follows: let us explore social practices, political projects and historical processes whereby locality, place, homeland, tradition, community, identity, ethnicity or nation are continually constituted within the context of local, regional and/or global entwinements. There are some other, salient questions we should be raising: How do the people of Oceania create and alter their places, communities and identities in the embodied performances of everyday life or collective ritual practices? How are differences between localities, groups and regions imagined, lived and negotiated? What role is played by power and inequality in this process of constructing relational configurations of human existence in Oceania?

The general prevalence of an analytic perspective foregrounding travel and migration, diaspora and trans-nationality within a context of global flows and interdependencies has certainly done its bit in calling into question and de-constructing old certainties of an «essential» nexus existing between places, people and cultures. But there is an attendant danger, that of applying essentialist categories to mobile and displaced people. Thus, for instance, Bell Hooks (1992) in her critique of James Clifford's «travelling theories» has pointed out that the manner in which mobility and movement is experienced can vary greatly, citing as examples the «Middle passage», the "Trail of tears», the landing of Chinese immigrants, the forced re-location of Japanese-Americans, and the plight of the homeless. In the Oceanian context, examples that spring to mind are the $19^{\text {th }}$ century «Labour Trade» (Moore, Leckie and Munro, 1990) and the multiple displacements of island peoples to meet colonial or neo-colonial exigencies of warfare, mining (Silverman, 1971; Kempf, 2004) or nuclear testing (Kiste, 1974; Carucci, 1997) in the $20^{\text {th }}$ century.

I will now show, by considering two contemporary cases from Fiji, the extent to which mobility, even now, is fraught with risks and dangers. The Fiji Times in a section headed «Postcards 
from Iraq - Fiji men adjust to the cold» published several reports by Fijians working in Baghdad as security guards - for companies like Global Risk International. One of the guards had this to say:

«But this [i.e. the cold weather, WK] has not deterred the insurgents from carrying out their daily activities on cars, buildings and other targets and explosions could be heard here on a daily basis, which has become a norm for us here. [...] As usual the grog sessions for those who drink grog [meant here is the drinking of kava, WK] still continue and the cold weather has not affected them in enjoying the traditional drink, which so far some expats from other countries have decided to try. [...] It's December and we are looking forward to making our famous lovo [Fijian for earth oven, WK]. We might miss our favourite bavia and cassava but we hope to enjoy whatever is available locally. [...] Would like to take this opportunity to convey my gesture of appreciation to all Fiji citizens abroad in Australia and the Cook Islands [...] Loloma [Fijian for love, WK] from all of us here in Iraq to everyone back home and may the blessings of the Lord be with us always.» (The Fiji Times, December 4, 2004: 7)

Whether through Kava drinking or setting up a Christmas lovo in the war-zone that is today's Baghdad, or using the Fiji Times as a forum to convey greetings from Iraq to fellow Fijians in Australia, the Cook Islands or back home in Fiji - Iraq at present figures greatly in the geographical imagination of Fijian communities in the Pacific. A large number of ethnic Fijians in Fiji are looking to parts of the Middle East where well-paid jobs can be had, in the hope of a better future. According to the Fiji Times of January 28, 2005, the contractor Homeland Security Agency employs 90 men in Iraq; another contractor, Global Risk, has since September 2003 hired some 800-1000 men for its Iraq operations; yet another contractor, Meridian Services Agency hired 200 Fijian men to work in Kuwait along with some 3000 Fijians recruited for future jobs in the Middle East. (Investigations of Meridian's recruitment practices, which include a job registration fee, have been initiated according to Fiji Islands Business magazine for April 2005).

Not all Fijians manage to land one of these tempting jobs, nor do all the «lucky» ones come back alive. Some six weeks ago, I got an e-mail from a Rotuman friend informing me that her younger brother had been killed in Iraq, along with other guards from Fiji, the U.S., and Bulgaria, when the helicopter they were being transported in was shot down. When the family gathered for the burial, it was discovered, to everyone's dismay, that there had been a «body mix-up» - as my friend called this distressing discovery. The mourners had to wait three weeks for the right body to be flown from the United States, where it had been erroneously dispatched; only then could the funeral take place and the dead be laid to rest.

«Global risk» and «body mix-up» are contemporary vignettes for movements and connections that permeate the daily living and the life plans of those in (and from) Oceania. Against this background, it is quickly apparent that any romanticising of mobile and displaced persons (and/or groups), such as results from theories restricting themselves to celebrating the subversive and de-stabilising potential of movement and interstitiality, skirts the realities in Pacific societies. In our session, therefore, it was particularly important not to lose sight of the detail of indigenous experiences, practices and politics as relayed in on-the-ground accounts. We need more differentiated perspectives, alive to the dynamics of how people, places and cultures relate in the Pacific and beyond. A sizeable step in that direction might be to assemble the insights of multiple disciplines; this would let us survey and compare (based on historically and ethnographically informed accounts), past and present movements, geographies and identities within Oceania. What we need to do is chart those configurations of movements, currents and interactions that lend to Oceanian timespaces their historically and culturally specific underpinnings, alignment and form.

\section{Part II: Themes in discussion}

We had a highly productive session involving some 15 papers and stimulating discussions, conducted in a pleasant atmosphere. The session was directed at achieving a dynamic, relational understanding of place, culture and identity in Oceania, alive no less to movement and mobility than to abiding/staying-at-home and stability. Each of these analyses of Oceanian societies was aligned to a historical or contemporary theme or else addressed a combination of both. The spectrum of contributions comprised, on one hand local and regional perspectives on reconfiguring place, culture and identity (among these were papers on societies that position themselves with their spatial practices and imaginings in rural contexts); on the other hand were contributions on social groups that reconstitute themselves in the wider matrix of rural-urban or inter-insular networks. This spectrum additionally comprised accounts of over-arching relationships, movements, flows and interactions, accounts tackling 
the historically and culturally specific alignments and formations of the various time-spaces of Oceania and its inhabitants.

Two poles of interest, shifting from migration and networking to rootedness and identity, were predominant. One investigates the movement or circulation of ideas, artefacts or people across space and examines the resulting broad exchange systems. Examples range from the construction of social and exchange networks that span the Australian Western Desert to recent historical changes in mobility and isolation caused by retraction of maritime trade on small isolated islands and expansion of road networks on the larger Melanesian islands. Another pole focuses on the local configuration of space through songs, toponyms and historical narratives. Such space, built up of memories and relationships is re-negotiated, re-affirmed and re-actualised generation after generation, although emically conceived of as a shared corpus of knowledge anchored in the past. The surrounding physical environment is dotted with named landmarks guarded by spirits, etc. to the point where the landscape becomes the society's mirror, the landscape reflecting or embodying their cosmology. Examples are the reconfiguration of an entire Micronesian landscape razed during WWII or pathways that reify the mythhistory of groups in the Solomon Islands and New Guinea. Historical events too, such as first encounters, WWII, changes in transport economics, internal migrations, which have affected geographies and boundaries, helped disentangle islanders' notions of space and locality. New network systems are being formed linking translocal or translocated communities with their homelands. These multivalent ways in which Oceania is being mapped and acted upon by islanders highlight the ideational dimension of landscapes.

\section{BIBLIOGRAPHY}

Bonnemaison Joël, 1985. The Tree and the Canoe: Roots and Mobility in Vanuatu Societies, in Murray Chapmann (ed.), Mobility and Identity in the Island Pacific, Pacific Viewpoint (Special Issue) 26 (1), pp. 30-62.

CARUCCI Laurence M., 1997. Nuclear Nativity. Rituals of Renewal and Empowerment in the Marshall Islands, DeKalb, Northern Illinois Press.

Clifford James, 1992. Travelling Cultures, in Lawrence Grossberg, Cary Nelson and Paula Treichler (eds), Cultural Studies, New York, Routledge, pp. 96-112.
- 1997. Routes: Travel and Translation in the Late 20th Century, Cambridge, MA, Harvard University Press.

DENING Greg, 1980. Islands and Beaches: Discourse on a Silent Land: Marquesas 1774 - 1880, Melbourne, Melbourne University Press.

—, 1998. Readings/Writings, Melbourne, Melbourne University Press.

—, 2004. Beach Crossings: Voyaging Across Times, Cultures and Self, Melbourne and Philadelphia, University of Pennsylvania Press.

Gupta Akhil and James Ferguson, 1997. Beyond "Culture": Space, Identity, and the Politics of Difference, in Akhil Gupta and James Ferguson (eds), Culture, Power, Place: Explorations in Critical Anthropology, Durham and London, Duke University Press, pp. 33-51.

Hau'ofa Epeli, 1993. Our Sea of Islands, in Eric Wadell, Vijay Naidu and Epeli Hau'ofa (eds), $A$ New Oceania: Rediscovering Our Sea of Islands, Suva, USP School of Social and Economic Development, pp. 2\&16.

Hooks Bell, 1992. Black Looks: Race and Representation, Boston, South End Press.

KEMPF Wolfgang, 2004. The Drama of Death as Narrative of Survival: Dance Theatre, Travelling and Thirdspace among the Banabans of Fiji, in Toon Van Meijl and Jelle Miedema (eds), Shifting Images of Identity in the Pacific, Leiden, KITLV Press, pp. 159-189.

Kiste Robert C., 1974. The Bikinians: A Study in Forced Migration, Menlo Park, Cummings.

LAviE Snadar and Ted SwedenburG, 1996. Introduction: Displacement, Diaspora, and Geographies of Identity, in Snadar Lavie and Ted Swedenburg (eds), Displacement, Diaspora, and Geographies of Identity, Durham and London, Duke University Press, pp. 1-25.

Moore Clive, Leckie Jacqueline and Doug Munro (eds), 1990. Labour in the South Pacific, Townsville, James Cook University of Northern Queensland.

Nero Karen L., 1997. The End of Insularity, in Donald Denoon and al. (eds), The Cambridge History of Pacific Islanders, Cambridge, Cambridge University Press, pp. 439-467.

Olwig Karen F. and Kirsten Hastrup (eds.), 1997. Siting Culture: The Shifting Anthropological Object, London and New York, Routledge.

PILE Steve and Nigel THrift, 1995. Mapping the Subject, in Steve Pile and Nigel Thrift (eds), Mapping the Subject: Geographies of Cultural Transformation, London and New York, Routledge, pp. 13-51.

Silverman Martin G., 1971. Disconcerting Issue: Meaning and Struggle in a Resettled Pacific Community, Chicago and London, The University of Chicago Press.

TomLInson John, 1999. Globalization and Culture, Chicago, University of Chicago Press. 